\title{
Penerapan Model Guided Inquiry Berbantukan Program One Day One Diary for Science terhadap Hasil Belajar dan Aktivitas Belajar Siswa pada Materi Suhu dan Kalor
}

\author{
Wiwit Susanty*, Suhartono \\ Program Studi Tadris Fisika, Jurusan Pendidikan Matematika dan Ilmu Pengetahuan Alam, Fakultas \\ Tarbiyah dan Ilmu Keguruan, IAIN Palangkaraya, Palangakaraya, Kalimantan tengah, Indonesia. \\ Email : Wiwitsusanty4@gmail.com
}

\begin{abstract}
Abstrak
Penelitian ini dilakukan untuk mengetahui perbedaan kemampuan hasil belajar siswa ranah kognitif dan psikomotorik serta aktivitas belajar siswa menggunakan model pembelajaran Guided Inquiry berbantukan program One Day One Diary for Science. Metode Quasy Experiment dengan model matching pretest-posttest comparison group design digunakan dengan pengambilan sampel menggunakan purposive sampling. Hasil menunjukkan peningkatan pada kemampuan hasil belajar kognitif dan psikomotorik siswa serta perbedaan aktivitas belajar siswa.

Kata Kunci: Model Guided Inquiry, Program One Day One Diary for Science, kognitif, psikomotorik, aktivitas belajar.

Abstract

This research was conducted to find out the differences in learning outcomes of students in the cognitive and psychomotor realms as well as student learning activities using guided inquiry learning models assisted by the One day one diary for science program. This research apply Purposive sampling by using Quasy Experiment method with matching model pretest-posttest comparison group design. The results showed improvements in students' cognitive and psychomotor learning outcomes as well as differences in students' learning activities.
\end{abstract}

Keywords: Model Guided Inquiry, One Day One Diary program for Science, cognitive, psychomotor, learning activities.

\section{PENDAHULUAN}

Salah satu permasalahan dalam pembelajaran fisika adalah kurangnya minat siswa terhadap materi-materi yang diajarkan. Kurangnya minat siswa dikarenakan siswa cenderung menganggap pelajaran fisika merupakan pelajaran yang sulit sehingga siswa kurang aktif dalam melakukan penyelidikan yang dapat mengakibatkan ketidakberhasilan dalam melakukan kerja kelompok (Jufri, 2013). Intensitas yang rendah dalam melakukan praktikum di laboratorium bertolak belakang dengan kondisi laboratorium di sekolah yang lengkap. Permasalahan yang berkaitan dengan proses belajar mengajar sehingga menyebabkan menurunnya hasil belajar siswa tersebut berimbas pada nilai ujian semester dan ujian kenaikan kelas. Oleh sebab itu, untuk menarik 
minat siswa diperlukan metode baru yang mengajak siswa lebih aktif dalam proses belajar mengajar sehingga proses pembelajaran tidak hanya terpaku pada guru dan buku pelajaran.

Berdasarkan data dari penyebaran angket yang dilakukan untuk mengetahui kemampuan siswa dalam memahami materi yang telah disampaikan oleh guru sebelum dilakukannya penelitian yaitu sebagai berikut: Persentase yang diperoleh untuk kelas XI-1 MIPA yaitu sebanyak $17,16 \%$ menyukai mata pelajaran fisika 25,67\%; kurang menyukai mata pelajaran fisika; dan $42,83 \%$ tidak menyukai mata pelajaran Fisika. Sedangkan, pada XI-2 MIPA yaitu $14,92 \%$ menyukai mata pelajaran fisika; 9,25\% siswa kurang menyukai mata pelajaran fisika; dan tidak menyukai sebanyak 75,83\%.

Model pembelajaran guided inqury merupakan rangkaian kegiatan pembelajaran yang menekankan siswa pada proses berfikir secara kritis dan analitis untuk mencari dan menemukan sendiri jawaban yang sudah pasti dari suatu masalah yang dipertanyakan (Sanjaya, 2006). Penerapan model pembelajaran Guided Inquiry dapat meningkatkan hasil belajar dan aktivitas siswa, serta mempengaruhi nilai kognitif dan psikomotorik yang berakibat pada aktivitas yang dilakukan siswa dalam meningkatkan pemahaman siswa dengan cara menerapkan program "One Day One Diary for Science" (Herlianti P.S., Linuwih S., Dwijananti P., 2015). Program tersebut diharapkan mampu memberikan konstribusi dalam pembelajaran Fisika untuk melatih kemampuan kognitif dan kemandirian siswa. Program ini juga diharapkan membantu siswa dan guru untuk memonitoring kegiatan pembelajaran untuk bagian yang dipahami dan tidak dipahami oleh siswa serta dapat mengetahui bagaimana tingkat pemahaman siswa tentang topik bahasan dan sub topik bahasan mata pelajaran Fisika tersebut.

Setiap hasil pengukuran selalu menunjukkan satu kesulitan. Namun, tidak membedakan antara satu kesulitan dan kesulitan berikutnya yang tercatat. Persepsi kesulitan dan aspek memiliki implikasi yang berbeda. Pengukuran siswa terhadap kesulitan materi yang dipelajari bervariasi sehingga akan menghasilkan identifikasi pemikiran yang berbeda pula. Interpretasi tersebut harus diurutkan siswa untuk memperoleh penyebab. Untuk tindak lanjut serta eksplorasi penilaian yang dinamis tentang persepsi kesulitan oleh siswa diperlukan solusi yang tepat (Erika A.P., S. Hooper, Ariana C. V., K. A. Pituch, R. R. Steingut., 2018). Program One day one diary for science adalah suatu program yang berkaitan dengan pemahaman siswa mengenai materi yang telah diajarkan pada pertemuan sebelumnya, dilihat dari catatan tersebut maka pengajar dapat menyimpulkan sejauh mana tingkat pemahaman siswa (Herlianti P.S., Linuwih S., Dwijananti P., 2015). Program One Day Diary for Science ini dapat dijadikan solusi untuk dapat eksplorasi penilaian yang dinamis terhadap kesulitan yang dihadapi siswa dalam mempelajari Fisika.

Materi suhu dan kalor merupakan salah satu sub materi yang sering ditemui dalam peristiwa 
sehari-hari, banyak peristiwa sehari-hari yang berkaitan dengan sub materi ini. Selain itu alat yang digunakan untuk melakukan praktikum juga mudah ditemukan dan dipraktikan sehingga dapat mempermudah siswa dan guru dalam melakukan praktikum.

Berdasarkan latar belakang tersebut, tujuan dalam penelitian ini adalah untuk mengetahui perbedaan antara hasil belajar siswa ranah kognitif dan psikomotorik serta aktivitas belajar siswa menggunakan model pembelajaran guided inqury berbantukan program one day one diary for science.

\section{METODE PENELITIAN}

Penelitian ini menggunakan penelitian kuantitatif yang menekankan pada analisis datadata (angka-angka) yang diolah dengan secara statistik. Jenis penelitian yang digunakan adalah penelitian kuasi eksperimen. Penelitian kuasi eksperimen dapat diartikan sebagai penelitian yang mendekati ekperimen atau eksperimen semu (Sukardi, 2007). Penelitian ini berusaha menjawab permasalahan yang diajukan peneliti tentang penggunaan model guided inqury dan model guided inqury program one day one diary

\section{HASIL DAN PEMBAHASAN}

\section{Hasil Belajar Kognitif}

Hasil belajar siswa diukur dengan menggunakan soal essay. Soal essay yang digunakan ini telah melalui uji validitas oleh Dosen ahli sebelum dipakai untuk mengambil data penelitian. Tes essay yang digunakan terdiri for science pada materi pokok bahasan suhu dan kalor.

Penelitian kuantitatif adalah suatu penelitian yang ditunjukan untuk mendeskripsikan dan menganalisis fenomena, peristiwa, aktivitas sosial, sikap, kepercayaan, persepsi, pemikiran orang secara individual maupun kelompok. Jenis penelitian eksperimen yang digunakan adalah Quasy Eksperimen Design. Sampel yang diambil pada penelitian ini adalah siswa yang memiliki kesamaan karakter dalam hal kecerdasan, keterampilan, kecakapan dan ketahanan fisik. Desain penelitian yang digunakan adalah Matching Pretest-Posttest Comparison Group Design, terdapat dua kelas yang dipilih dan tidak dipilih secara acak, kemudian diberi pretest untuk mengetahui keadaan awal, adakah perbedaan antara kelas eksperimen 1 dan kelas Eksperimen. Kelas kontrol diberi perlakuan dengan menggunakan pembelajaran Guided Inquir, sedangkan kelas Eksperimen menggunakan model Guided Inquiry berbantukan Program One Day One Diary For Science. Setelah selesai perlakuan kedua kelas diberi posttest (Arikunto, 2013).

dari 15 butir soal. Tes dilakukan dengan membandingkan tes sebelum (pre-test) dan sesudah (post-test) mengikuti pembelajaran fisika pada materi Suhu dan Kalor dengan menerapkan model pembelajaran Guided Inqury pada kelas kontrol dan Guided Inqury berbantukan program one day one diary for science pada kelas eksperimen. 
Tabel 1. Nilai rata-rata pretest, posttest, gain dan N-gain Hasil Belajar Kognitif

\begin{tabular}{|c|c|c|c|c|c|}
\hline \multirow[b]{2}{*}{ Kelas } & \multirow[b]{2}{*}{$\mathbf{N}$} & \multicolumn{4}{|c|}{ Rata-rata } \\
\hline & & $\begin{array}{c}\text { Pre- } \\
\text { test }\end{array}$ & $\begin{array}{c}\text { Post- } \\
\text { Test }\end{array}$ & Gain & $\begin{array}{c}\text { N- } \\
\text { Gain }\end{array}$ \\
\hline Kontrol & 36 & 9,508 & 56,125 & 46,616 & 0,5164 \\
\hline Eksperimen & 36 & 19,834 & 63,402 & 43,568 & 0,5420 \\
\hline
\end{tabular}

Berdasarkan Tabel 1, peningkatan hasil belajar kognitif siswa setelah penerapan model pembelajaran guided inqury dan guided inqury berbantukan program one day one diary for sciencs dilakukan dimana pada kelas kontrol nilai pretest siswa rata-rata sebesar 9,508 dan setelah menggunakan model guided inqury menjadi 56,125. Pada kelas eksperimen nilai pretest siswa rata-rata sebesar 19,834 dan setelah diterapkannya model guided inqury berbantukan program one day one diary for sciencs sebanyak 63,402.

\section{Hasil Belajar Psikomotorik}

Hasil belajar psikomotorik diukur pada saat proses belajar mengajar berlangsung dengan cara pengamatan yang dilakukan oleh pengawas akhli dari mahasiswa Pendidikan Fisika IAIN Palangka Raya yang juga sedang melakukan penelitian.

Tes dilakukan dengan membandingkan tes sebelum (pre-test) dan sesudah (post-test) mengikuti pembelajaran fisika pada materi Suhu dan Kalor dengan menerapkan model pembelajaran Guided Inqury pada kelas kontrol dan Guided Inqury berbantukan program one day one diary for science pada kelas eksperimen. Hasil analisis tes uraian ini yaitu menggunakan program MS. Excel dan SPSS versi 17.0. data yang diperoleh terdiri pada Tabel 2 sebagai berikut.

Tabel 2. Nilai rata-rata pretest, posttest, gain dan N-gain Hasil Belajar Psikomotorik

\begin{tabular}{lccccc}
\hline \multirow{2}{*}{ Kelas } & N & \multicolumn{4}{c}{ Rata-rata } \\
\cline { 3 - 6 } & & $\begin{array}{c}\text { Pre- } \\
\text { test }\end{array}$ & $\begin{array}{c}\text { Post- } \\
\text { Test }\end{array}$ & Gain & $\begin{array}{c}\text { N- } \\
\text { Gain }\end{array}$ \\
\hline Kontrol & 36 & 59,48 & 70,86 & 11,37 & 0,43 \\
\hline Eksperimen & 36 & 65,16 & 68,14 & 2,98 & 0,08 \\
\hline
\end{tabular}

Berdasarkan Tabel 2, peningkatan hasil belajar Psikomotorik siswa setelah dilakukannya penerapan model pembelajaran guided inqury dan guided inqury berbantukan program one day one diary for science dimana pada kelas Kontrol nilai pre-test siswa rata-rata sebesar 59,48 dan setalah menggunakan model gudid inqury menjadi 70,86. Untuk kelas eksperimen nilai pre-test siswa rata-rata sebesar 65,16 dan setelah diterapkannya model guided inqury berbantukan program one day one diary for science sebanyak 68,14 .

\section{Hasil Penelitian Aktivitas Siswa}

\section{Aktivitas Siswa menggunakan Model Pembelajaran Guided Inquiry}

Aktivitas siswa kelas Kontrol dapat diukur pada saat proses belajar mengajar berlangsung dengan dibantu oleh 4 orang pengamat akhi mahasiswa Pendidikan Fisika IAIN Palangka Raya. Masing-masing pengamat mencatat hasil pengamatan pada lembar aktivitas siswa yang telah di sediakan. Pengamatan dilakukan terhadap 36 siswa Kelas XI-2 MIPA SMA 
Negeri 4 Palangka Raya. Rekapitulasi aktivitas

model pembelajaran guided inquiry pada Tabel siswa pada tiap pertemuan dalam penerapan

3.

Tabel 3. Hasil Pengamatan Aktivitas Siswa Kelas Kontrol Menggunakan Model Guided Inquiry

\begin{tabular}{|c|c|c|c|c|c|c|}
\hline \multirow[t]{2}{*}{ No } & \multirow{2}{*}{$\begin{array}{c}\text { Aktivitas Pembelajaran } \\
\text { Aspek Yang Diamati }\end{array}$} & \multicolumn{3}{|c|}{$\begin{array}{c}\text { Persentase Nilai Tiap Aspek } \\
(\%)\end{array}$} & \multirow{2}{*}{$\begin{array}{c}\text { Rata- } \\
\text { Rata } \\
(\%)\end{array}$} & \multirow[t]{2}{*}{ Kategori } \\
\hline & & RPP 1 & RPP 2 & RPP 3 & & \\
\hline & \multicolumn{6}{|l|}{ Kegiatan Inti } \\
\hline & \multicolumn{6}{|l|}{ Fase 1: Merumuskan Masalah } \\
\hline 1 & $\begin{array}{l}\text { Siswa memperhatikan dan } \\
\text { mendengarkan pertanyaan- } \\
\text { pertanyaan hipotesis yang } \\
\text { diajukan guru }\end{array}$ & 59,55 & 78,67 & 77,20 & 71.81 & Baik \\
\hline 2 & $\begin{array}{l}\text { Siswa memisahkan diri menuju } \\
\text { kelompoknya masing-masing }\end{array}$ & 59,55 & 78,67 & 77,20 & 71.81 & Baik \\
\hline 3 & Siswa mengambil LKPD & 59,55 & 78,67 & 77,20 & 71.81 & Baik \\
\hline 4 & $\begin{array}{l}\text { Siswa bersama kelompoknya } \\
\text { merumuskan masalah sesuai } \\
\text { permasalahan yang diberikan }\end{array}$ & 59,55 & 78,67 & 77,20 & 71.81 & Baik \\
\hline & \multicolumn{6}{|l|}{ Fase 2: Membuat Hipotesis } \\
\hline 5 & $\begin{array}{l}\text { Siswa dalam kelompok } \\
\text { berdiskusi membuat hipotesis } \\
\text { dari rumusan masalah yang } \\
\text { telah dibuat sesuai dengan } \\
\text { permasalahan yang diberikan } \\
\text { guru }\end{array}$ & 55,14 & 69,11 & 75 & 66.42 & Cukup Baik \\
\hline 6 & $\begin{array}{l}\text { Siswa membuat hipotesis awal } \\
\text { dari permasalahan yang telah } \\
\text { disajikan pada LKPD }\end{array}$ & 55,14 & 69,11 & 75 & 66.42 & Cukup Baik \\
\hline & \multicolumn{6}{|l|}{ Fase 3 Merancang Percobaan } \\
\hline 7 & $\begin{array}{l}\text { Siswa dalam kelompok ikut } \\
\text { menyiapkan alat dan bahan } \\
\text { pecobaan sesuai dengan LKPD }\end{array}$ & 55,14 & 72,05 & 82,35 & 69,85 & Baik \\
\hline 8 & $\begin{array}{l}\text { Siswa menentukan alat dan } \\
\text { bahan yang sesuai untuk } \\
\text { memecahkan permasalahan }\end{array}$ & 55,14 & 72,05 & 82,35 & 69,85 & Baik \\
\hline 9 & $\begin{array}{l}\text { Siswa bersama kelompok } \\
\text { berdiskusi membuat langkah- } \\
\text { langkah percobaan secara rinci }\end{array}$ & 55,14 & 72,05 & 82,35 & 69,85 & Baik \\
\hline \multicolumn{7}{|c|}{ Fase 4 Melaksanakan Kegiatan } \\
\hline 10 & $\begin{array}{l}\text { Siswa dalam kelompok ikut } \\
\text { bekerja sama dalam } \\
\text { kelompoknya mengerjakan } \\
\text { LKPD dengan bimbingan guru }\end{array}$ & 55,14 & 77,20 & 81,61 & 71,32 & Baik \\
\hline \multicolumn{7}{|c|}{ Fase 5: Mengumpulkan dan menganalisis data } \\
\hline 11 & $\begin{array}{l}\text { Siswa mengumpulkan data } \\
\text { hasil percobaan dalam bentuk } \\
\text { tabel. }\end{array}$ & 54,41 & 74,26 & 74,26 & 67,64 & Cukup Baik \\
\hline
\end{tabular}




\begin{tabular}{|c|c|c|c|c|c|c|}
\hline \multirow[t]{2}{*}{ No } & Aktivitas Pembelajaran & \multicolumn{3}{|c|}{$\begin{array}{c}\text { Persentase Nilai Tiap Aspek } \\
(\%)\end{array}$} & \multirow{2}{*}{$\begin{array}{c}\text { Rata- } \\
\text { Rata } \\
(\%)\end{array}$} & \multirow[t]{2}{*}{ Kategori } \\
\hline & Aspek Yang Diamati & RPP 1 & RPP 2 & RPP 3 & & \\
\hline 12 & $\begin{array}{l}\text { Siswa mendiskusikan analisis } \\
\text { data hasil percobaan }\end{array}$ & 54,41 & 74,26 & 74,26 & 67,64 & CukupBaik \\
\hline 13 & $\begin{array}{l}\text { Siswa mengerjakan pertayaan } \\
\text { diskusi }\end{array}$ & 54,41 & 74,26 & 74,26 & 67,64 & Cukup Baik \\
\hline \multicolumn{7}{|c|}{ Fase 6: Generalization (Menyimpulkan) } \\
\hline 14 & $\begin{array}{l}\text { Masing-masing } \\
\text { menyimpulkan hasil diskusi } \\
\text { yang telah dilakukan. }\end{array}$ & 56,61 & 71,32 & 77,94 & 66,62 & Cukup Baik \\
\hline
\end{tabular}

Tabel 3 merupakan hasil pengamatan yang telah dilakukan untuk aktivitas belajar siswa selama mengikuti proses belajar mengajar pada kelas kontrol dimana setiap pertemuan siswa mengalami peningkatan meskipun tidak terlalu menonjol namun sesuai dengan harapan penulis. Dengan begitu dapat dikatakan berhasil dalam proses pembelajaran dengan menggunakan model pembelajaran guided inqury berbantukan program one day one diary for science terhadap Aktivitas Siswa menggunakan Model Pembelajaran Guided Inquiry Berbantukan Program One Day One Diary for Science

Aktivitas siswa pada kelas eksperimen menggunakan model pembelajaran Guided Inquiry dinilai melalui lembar pengamatan yang diamati oleh 4 orang pengamat yang telah mengamati aktivitas siswa untuk 3 kali pertemuan. aktivitas belajar siswa di kelas XI-1 dan XI-2 MIPA SMA Negeri 4 Palangka Raya.

Tabel 4. Hasil Pengamatan Aktivitas Kelas Eksperimen

\begin{tabular}{|c|c|c|c|c|c|c|}
\hline \multirow[t]{2}{*}{ No } & \multirow{2}{*}{$\begin{array}{c}\text { Aktivitas Pembelajaran } \\
\text { Aspek Yang Diamati }\end{array}$} & \multicolumn{3}{|c|}{$\begin{array}{c}\text { Persentase Nilai Tiap Aspek } \\
(\%)\end{array}$} & \multirow{2}{*}{$\begin{array}{l}\text { Rata- } \\
\text { Rata } \\
(\%)\end{array}$} & \multirow[t]{2}{*}{ Kategori } \\
\hline & & RPP 1 & RPP 2 & RPP 3 & & \\
\hline & \multicolumn{6}{|l|}{ Kegiatan Inti } \\
\hline & \multicolumn{6}{|l|}{ Fase 1: Merumuskan Masalah } \\
\hline 1 & $\begin{array}{l}\text { Siswa mendengarkan } \\
\text { konfirmasi dari guru tentang } \\
\text { kesimpulan materi sebelumnya } \\
\text { yang belum siswa pahami pada } \\
\text { pertemuan sebelumnya }\end{array}$ & 71,32 & 71,32 & 74,26 & 72,79 & Baik \\
\hline 2 & $\begin{array}{l}\text { Siswa memperhatikan dan } \\
\text { mendengarkan pertanyaan- } \\
\text { pertanyaan hipotesis yang } \\
\text { diajukan guru }\end{array}$ & 63,97 & 71,32 & 74,26 & 69,85 & Cukup Baik \\
\hline 3 & Siswa memisahkan diri menuju & 63,97 & 71,32 & 74,26 & 69,85 & CukupBaik \\
\hline
\end{tabular}




\begin{tabular}{|c|c|c|c|c|c|c|}
\hline \multirow[t]{2}{*}{ No } & \multirow{2}{*}{\begin{tabular}{|c|} 
Aktivitas Pembelajaran \\
Aspek Yang Diamati \\
\end{tabular}} & \multicolumn{3}{|c|}{$\begin{array}{c}\text { Persentase Nilai Tiap Aspek } \\
(\%)\end{array}$} & \multirow{2}{*}{$\begin{array}{c}\text { Rata- } \\
\text { Rata } \\
(\%)\end{array}$} & \multirow[t]{2}{*}{ Kategori } \\
\hline & & RPP 1 & RPP 2 & RPP 3 & & \\
\hline & kelompoknya masing-masing & & & & & \\
\hline 4 & Siswa mengambil LKPD & 63,97 & 71,32 & 74,26 & 69,85 & Baik \\
\hline \multirow[t]{2}{*}{5} & $\begin{array}{l}\text { Siswa bersama kelompoknya } \\
\text { merumuskan maslah sesuai } \\
\text { permasalahan yang diberikan }\end{array}$ & 63,97 & 71,32 & 74,26 & 69,85 & Cukup Baik \\
\hline & Fase 2: Membuat Hipotesis & & & & & \\
\hline 6 & $\begin{array}{l}\text { Siswa dalam kelompok } \\
\text { berdiskusi membuat hipotesis } \\
\text { dari rumusan masalah yang } \\
\text { telah dibuat sesuai dengan } \\
\text { permasalahan yang diberikan } \\
\text { guru }\end{array}$ & 54,54 & 72,05 & 72,05 & 66,22 & Cukup Baik \\
\hline \multirow[t]{2}{*}{7} & $\begin{array}{l}\text { Siswa membuat hipotesis } \\
\text { awal dari permasalahan yang } \\
\text { telah disajikan pada LKPD }\end{array}$ & 54,54 & 72,05 & 72,05 & 66,22 & Cukup Baik \\
\hline & Fase 3 Merancang Percobaan & & & & & \\
\hline 8 & $\begin{array}{l}\text { Siswa dalam kelompok } \\
\text { ikut menyiapkan alat dan bahan } \\
\text { pecobaan sesuai dengan LKPD }\end{array}$ & 57,352 & 69,85 & 72,79 & 72,79 & Baik \\
\hline 9 & $\begin{array}{l}\text { Siswa menentukan alat } \\
\text { dan bahan yang sesuai untuk } \\
\text { memecahkan permasalahan }\end{array}$ & 57,35 & 69,85 & 72,79 & 66,66 & Cukup Baik \\
\hline \multirow[t]{2}{*}{10} & $\begin{array}{l}\text { Siswa bersama kelompok } \\
\text { berdiskusi membuat langkah- } \\
\text { langkah percobaan secara rinci }\end{array}$ & 57,35 & 69,85 & 72,79 & 66,66 & Cukup Baik \\
\hline & Fase 4 Melaksanakan Kegiatan & & & & & \\
\hline 11 & $\begin{array}{l}\text { Siswa dalam kelompok } \\
\text { ikut bekerja sama dalam } \\
\text { kelompoknya mengerjakan } \\
\text { LKPD dengan bimbingan guru }\end{array}$ & 63,23 & 69,11 & 72,79 & 68,38 & Cukup Baik \\
\hline \multicolumn{7}{|c|}{ Fase 5: Mengumpulkan dan menganalisis data } \\
\hline 12 & $\begin{array}{l}\text { Siswa mengumpulkan } \\
\text { data hasil percobaan dalam } \\
\text { bentuk tabel. }\end{array}$ & 60,29 & 66,91 & 71,32 & 66,17 & Cukup Baik \\
\hline 13 & $\begin{array}{l}\text { Siswa mendiskusikan } \\
\text { analisis data hasil percobaan }\end{array}$ & 60,29 & 66,91 & 71,32 & 66,17 & Cukup Baik \\
\hline 14 & $\begin{array}{c}\text { Siswa } \\
\text { pertayaan diskusi }\end{array}$ & 60,29 & 66,91 & 71,32 & 66,17 & Cukup Baik \\
\hline & Fase 6: Generalization (Menyim/ & ulkan) & & & & \\
\hline 15 & $\begin{array}{l}\text { Masing-masing kelompok } \\
\text { menyimpulkan hasil diskusi } \\
\text { yang telah dilakukan. }\end{array}$ & 64,70 & 70,58 & 69,11 & 68,13 & Cukup Baik \\
\hline 16 & \begin{tabular}{l}
\multicolumn{3}{c}{ Siswa Menuliskan materi } \\
yang siswa pahami pada \\
petemuan ini.
\end{tabular} & 65,80 & 66,17 & 65,44 & 65,80 & Cukup Baik \\
\hline
\end{tabular}


Apabila dilakukan perbandingan antara Tabel 3 dan Tabel 4 maka akan terlihat perbedaan untuk setiap fasenya. Pada fase merumuskan masalah, kelas kontrol tidak memperoleh satu tahap, yaitu siswa mendengarkan konfirmasi dari guru tentang kesimpulan materi sebelumnya yang belum siswa pahami pada pertemuan sebelumnya. Kelas kontrol memperoleh rerata persentase nilai tiap aspek 71,81\%. Sedangkan, Kelas eksperimen memperoleh rerata persentase nilai tiap aspek 70,44\%. Hal ini menunjukkan bahwa fase merumuskan masalah untuk pembelajaran dengan model Guided Inqury berbantukan Program One day one diary for science memberikan rerata lebih rendah dibandingkan dengan yang tidak Berbantukan Program One Day One Diary for Science.

Pada fase kedua (membuat hipotesis), fase ketiga (merancang percobaan), fase keempat (melaksanakan kegiatan), dan fase kelima (mengumpulkan dan menganalisis data) tidak ada perbedaan tahap. Mulai dari fase kedua hingga fase kelima, rerata persentase nilai tiap aspek pada kelas eksperimen lebih rendah dibandingkan dengan rerata persentase nilai tiap aspek pada kelas kontrol. Tidak ada perbedaan tahap tetapi pemberian bantuan Program One day one diary for science tidak memberikan rerata lebih tinggi memunculkan implikasi yan bersifat substantif, yaitu untuk tindak lanjut membentuk minat yang tinggi oleh siswa terhadap mata pelajaran fisika.
Kelas eksperimen memberikan rerata persentase nilai tiap aspek yang lebih dibandingkan dengan kelas kontrol, yaitu $66,96 \%>66,62 \%$. Hal tersebut menunjukkan solusi terhadap implikasi pada fase keenam ialah Siswa Menuliskan materi yang siswa pahami pada petemuan ini. Walaupun dari fase pertama hingga fase kelima, kelas eksperimen memiliki persentase lebih rendah dibandingkan dengan pada kelas kontrol, tidak dapat langsung disimpulkan bahwa bantuan Program One day one diary for science tidak boleh menjadi solusi dalam meningkatkan minat siswa terhadap mata pelajaran fisika karena harus ada tindak lanjut terhadap faktor yang berkaitan dengan minat siswa yang di antaranya ialah self-integrated.

\section{SIMPULAN}

Berdasarkan hasil dan pembahasan, kelas eksperimen memperoleh N-Gain lebih tinggi dibandingkan dengan kelas kontrol dalam hasil belajar kognitif. Kelas eksperimen memperoleh N-Gain lebih rendah dibandingkan dengan kelas kontrol dalam hasil belajar psikomotorik. Hal tersebut menunjukkan bahwa model Guided Inquiry berbantukan program one day one diary for science memberikan tidak efektif untuk hasil belajar psikomotorik. Aktivitas siswa pada kelas eksperimen dan kelas kontrol dibedakan pada fase pertama dan fase keenam yang mana hanya fase keenam yang menunjukkan rerata persentase yang lebih tinggi pada kelas eksperimen di antara keenam fase yang dilakukan. 


\section{DAFTAR PUSTAKA}

Arikunto, S. (2013). Dasar-Dasar Evaluasi Pendidikan Edisi 2. Jakarta: Bumi Aksara.

Erika A.P., S. Hooper, Ariana C. V., K. A. Pituch, R. R. Steingut. (2018). Science class is too hard: Preceived difficulty, disengagement, and the role of teacher autonomy support from a daily diary pespective. Learning and Instruction, 58, 220-231. Retrieved from https://www.sciencedirect.com/science/a rticle/pii/S0959475217304942
Herlianti P.S., Linuwih S., Dwijananti P. (2015). Independent Learning Strategy Of Natural Science With One day one diary for science Program. Jurnal Pendidikan Fisika, 11(2), 148-155.

Jufri, A. (2013). Belajar dan Pembelajaran Sains. Bandung: Pustaka Reka Cipta.

Sanjaya, W. (2006). Strategi Pembelajaran Berorientasi Standar Proses Pendidikan. Jakarta: Prenada Media.

Sukardi. (2007). Metodologi Penelitian Pendidikan. Jakarta: Bumi Aksara. 